\title{
Urinary Excretion of Adrenaline and \\ Noradrenaline in Holstein Calves \\ during Heat and Cold Exposure
}

\author{
Masato Nakamura and Tetsu Nemoto \\ National Institute of Animal Industry, Tsukuba \\ Norinkenkyudanchi, Ibaraki-ken 305
}

(Received April 2, 1992)

\begin{abstract}
The effects of environmental temperature upon the sympathetic nervous system and adrenal medulla of Holstein calves were examined to assess characteristics of the self auto-regulation system. To these aims this study describes the urinary excretion of adrenaline and noradrenaline of Holstein calves housed in a climate controlled room at $10^{\circ} \mathrm{C}, 20^{\circ} \mathrm{C}$ and $30^{\circ} \mathrm{C}$ was measured by high-performance liquid chromatography with the trihydroxyindole fluorimetric procedure. The experimental animals were housed in a climate room at $20^{\circ} \mathrm{C}$ for five days, then exposed for four or five days to $10^{\circ} \mathrm{C}, 20^{\circ} \mathrm{C}$ and $30^{\circ} \mathrm{C}$. The animals were fed two liters of milk twice daily, with no other supplemental food nor water. Urine was collected continuously by a self-retaining urethral catheter. The mean value of daily urine volume was maximum at $10^{\circ} \mathrm{C}$, and decreased with increasing environmental temperature. The mean value of daily urine volume at $30^{\circ} \mathrm{C}$ was significantly $(\mathrm{P}<0.05)$ smaller than the values obtained during other environmental temperatures. When the calves were exposed to $10^{\circ} \mathrm{C}$, the mean value of noradrenaline excretion increased significantly $(\mathrm{P}<0.05)$ from $20.9 \mu \mathrm{g} / \mathrm{day}$ at $20^{\circ} \mathrm{C}$ to $38.1 \mu \mathrm{g} /$ day at $10^{\circ} \mathrm{C}$. The mean value of adrenaline excretion increased from $3.2 \mu \mathrm{g} /$ day at $20^{\circ} \mathrm{C}$ to $4.1 \mu \mathrm{g} /$ day at $10^{\circ} \mathrm{C}$. During exposure at $30^{\circ} \mathrm{C}$, daily excretion of noradrenaline and adrenaline was not significantly affected.

Anim. Sci. Technol. (Jpn.) 63 (11) : 1134-1141, 1992
\end{abstract}

Key words : adrenaline, noradrenaline, urine,Holstein calf,environmental temperature

Urinary excretion of adrenaline and noradrenaline has been used by several investigators for evaluation of the sympathetic nervous system and adrenal medullary activity during heat and cold exposure. During heat and cold exposure, an increase in urinary noradrenaline has been observed in the rat ${ }^{9,13,15)}$ and in $\operatorname{man}^{4,7,8)}$. The increase in urinary excretion of adrenaline (A) and noradrenaline (NA) during exposure to heat and cold implies an important role of the adrenergic nervous system and the adrenal glands ${ }^{3}$. Despite the prevalence of studies on excretion of $\mathrm{A}$ and NA, observations on the ruminant are scarce ${ }^{1,2,12)}$. Our experi- ment was designed to study the effects of cold $\left(10^{\circ} \mathrm{C}\right)$ and heat exposure $\left(30^{\circ} \mathrm{C}\right)$ on the sympathetic nervous system and adrenal medulla of Holstein calves by measuring urinary excretion of $\mathrm{A}$ and NA.

\section{Materials and Methods}

Four young (1-2 weeks old) female Holstein calves (body weight: $34.0,48.5,49.5,50.0 \mathrm{~kg}$ ) were housed in a climatic room. The animals were secured by a neck chain, and were fed two liters of milk twice daily at 9 a.m. and 4 p.m., with no other supplemental food nor water. Light was provided from 6 a.m. to 6 p.m. The 


\section{Urinary Catecholamines in Holstein Calves}

experimental schedule of treatment was divided into four periods. The animals were exposed for four or five days to each climatic condition. In the first and third period, the environment was kept at $20^{\circ} \mathrm{C}$ and $60 \%$ relative humidity. In the second period, the environment was kept at $10^{\circ} \mathrm{C}$ and $80 \%$ relative humidity. In the fourth period, the environment was kept at $30^{\circ} \mathrm{C}$ and $60 \%$ relative humidity. Changes in the climatic condition in the room at the end of the each period were begun at $10 \mathrm{a} . \mathrm{m}$. and completed within one hour.

Urine was collected continuously by a selfretaining urethral catheter (Bardex foley catheter No. 8, Bard Inc., U.S.A.). The bladder was drained by continuous siphonage into a polyethylene bottle containing $20 \mathrm{~m} l$ of $6 \mathrm{~N} \mathrm{HCl}$ to keep urine below $\mathrm{pH} 3{ }^{10)}$. Urine was collected each 12 hours of daytime ( 6 a.m. -6 p.m.) and nighttime (6 p.m. -6 a.m.) using an electromagnetic valve and time switch. Urine volume was measured by a graduated cylinder after 12 hours of collection, and the samples were stored at $-20^{\circ} \mathrm{C}$ until later analysis.

Vaginal temperature was measured using a thermistor probe. The $R-R$ interval was measured from one peak to the next peak in the ECG with sampling frequency of $1 \mathrm{~ms}$. Then heart rate was converted from each $R-R$ interval employing a microcomputer. Respiration rate was measured using a thermistor sensor attached to a nose ring of calf. These data were stored every 24 hours on a hard disk in a microcomputer via $\mathrm{I} / \mathrm{O}$ interface. The physiological responses in calves during each environmental condition were obtained from the stored data between 1 p.m. to 2 p.m. in everyday in this study.

Two $\mathrm{m} l$ of thawed urine was hydrolyzed at $100^{\circ} \mathrm{C}$ for $20 \mathrm{~min}$ in a water bath incubator. To a $2 \mathrm{~m} l$ volume of hydrolyzed urine, $20 \mathrm{mg}$ of alumina (02120, Woelm Inc., Germany) and $0.8 \mathrm{~m} l$ of Tris buffer, $\mathrm{pH} 8.6$, and $100 \mu l$ of 0.15 M EDTA-2 Na solution, $\mathrm{pH} 7$, were added ${ }^{6}$. The $\mathrm{pH}$ of the mixture was adjusted between 8 to 9 with $1 \mathrm{~N} \mathrm{NaOH}$. The tube was then placed in a shaker and was shaken for $20 \mathrm{~min}$. The alumina was then washed two times by mixing for a few seconds with $5 \mathrm{ml}$ of $3 \mathrm{mM}$ EDTA-2 $\mathrm{Na}$ solution, $\mathrm{pH} 7^{6)}$. The amines were eluted from the alumina by voltexing for $3 \mathrm{~min}$ with $200 \mu l$ of $1 \mathrm{~N}$ acetic acid. After centrifugation, $50 \mu l$ of the supernatant layer was analyzed by high-performance liquid chromatography.

High-performance liquid chromatography with the trihydroxyindole fluorimetric procedure ${ }^{10,16)}$ was used to measure levels of $A$ and NA. These catecholamines were detected by a spectrofluorophotometer (FP-540D, Japan Spectroscopic Co. Ltd., Tokyo) at an excitation wavelength of $395 \mathrm{~nm}$ and an emission wavelength of $500 \mathrm{~nm}$ and were integrated as peak areas. Furthermore, these peaks were calculated quantitatively from the values of the catecholamine standard which was passed through the test procedure simultaneously.

Students' t-test was used to determine differences between means.

\section{Results}

Chromatograms obtained for $2 \mathrm{ml}$ of urine and the standard of $250 \mathrm{pg} \mathrm{A}$ and NA are shown in Fig. 1. Fluorimetric detection limits were $10 \mathrm{pg}$ for $\mathrm{A}$ and $30 \mathrm{pg}$ for NA (signal/peak-topeak noise ratio of 2). The within-day coefficient of variation for identical standard solutions was $6.8 \%$ for $\mathrm{A}(\mathrm{n}=4)$ and $2.0 \%$ for $\mathrm{NA}$ $(n=4)$. Absolute recoveries (means \pm S.D.) of $A$ and NA were $61.6 \pm 5.9 \%(n=6)$ and $57.7 \pm$ $4.1 \%(n=6)$, respectively, when the amount of standard added was varied over a wide range $(100 \mathrm{pg}-10 \mathrm{ng} / \mathrm{ml})$.

Changes in daily vaginal temperature, heart rate and respiration rate are shown in Fig. 2. The vaginal temperatures and respiration rate increased at $30^{\circ} \mathrm{C}$. The mean value of vaginal temperatures at $30^{\circ} \mathrm{C}$ was significantly $(\mathrm{P}<$ $0.05)$ higher than the values obtained at $10^{\circ} \mathrm{C}$. Heart rates showed a slight tendency to in- 


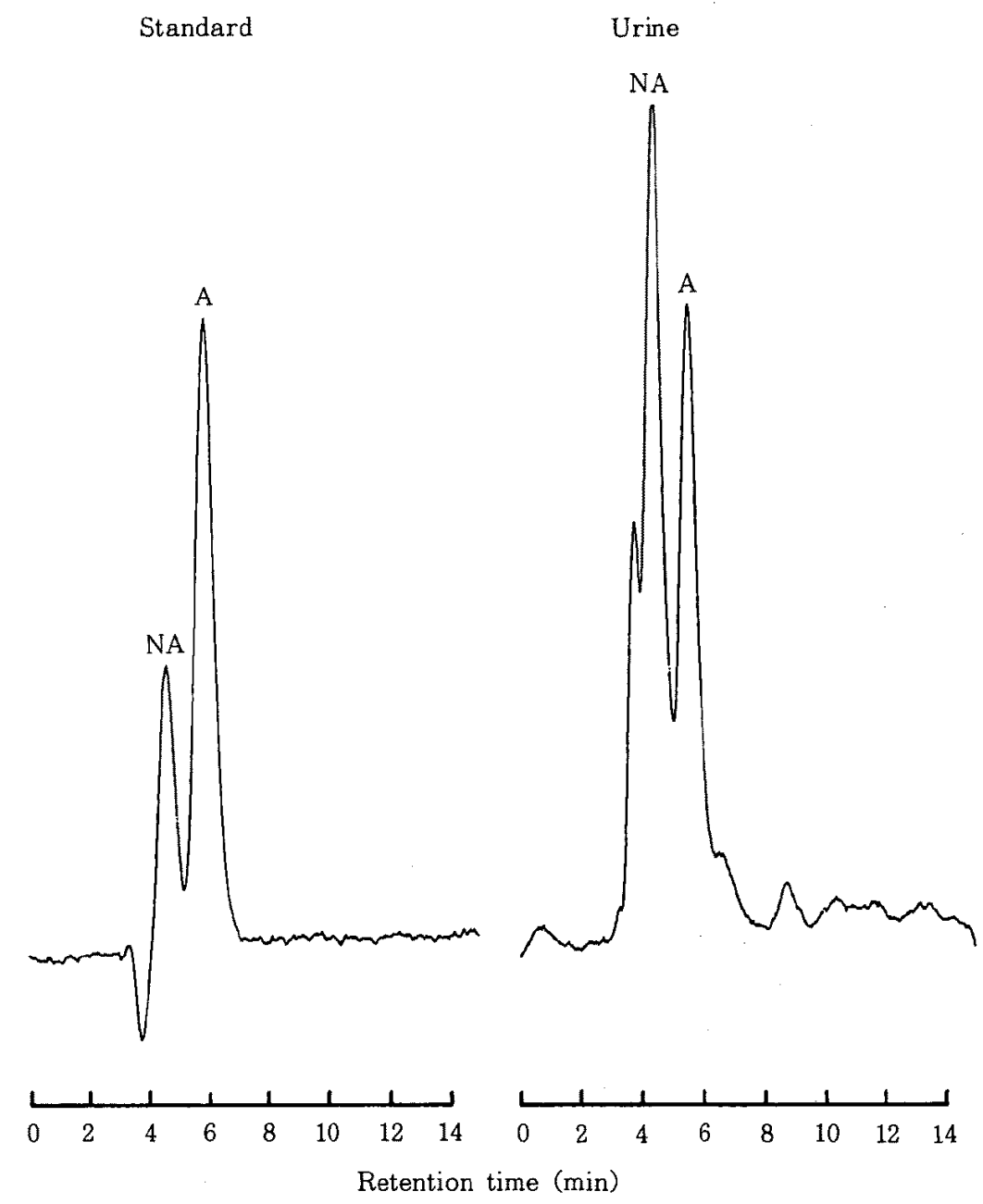

Fig. 1. Chromatograms of catecholamine standard (250 pg each of noradrenaline (NA) and adrenaline (A)) and calf urine sample.

Conditions: sample size $50 \mu l$; column, Catecholpak $(150 \mathrm{~mm} \times 4.5 \mathrm{~mm}$ I.D.) ; mobile phase, $0.1 \mathrm{M} \mathrm{KH}_{2} \mathrm{PO}_{4}, \mathrm{pH} 3.2$; flow-rate, $0.8 \mathrm{ml} / \mathrm{min}$; column temperature, $40^{\circ} \mathrm{C}$; spectrofluorophotometer excitation wavelength, $395 \mathrm{~nm}$; emission wavelength, $500 \mathrm{~nm}$.

crease at $10^{\circ} \mathrm{C}$. The increase in the heart rates, however, was not statistically significant (Table 1). Respiration rate at $30^{\circ} \mathrm{C}$ was significantly $(P<0.05)$ higher than the values obtained during other environmental temperatures (Table 1). Changes in daily urine volume are shown in Fig. 3. The daily urine volume was maximum at $10^{\circ} \mathrm{C}$, and decreased with increasing environmental temperature. The mean value of daily urine volume at $30^{\circ} \mathrm{C}$ was significantly $(\mathrm{P}<0.05)$ smaller than the values obtained during other environmental temperatures (Table 1).

Changes in the daily excretion of urinary NA are shown in Fig. 3. Mean value of NA excretion was $20.9 \mu \mathrm{g} /$ day at $20^{\circ} \mathrm{C}$ (Table 1.). When the environmental temperature was decreased to $10^{\circ} \mathrm{C}$, NA excretion increased significantly 


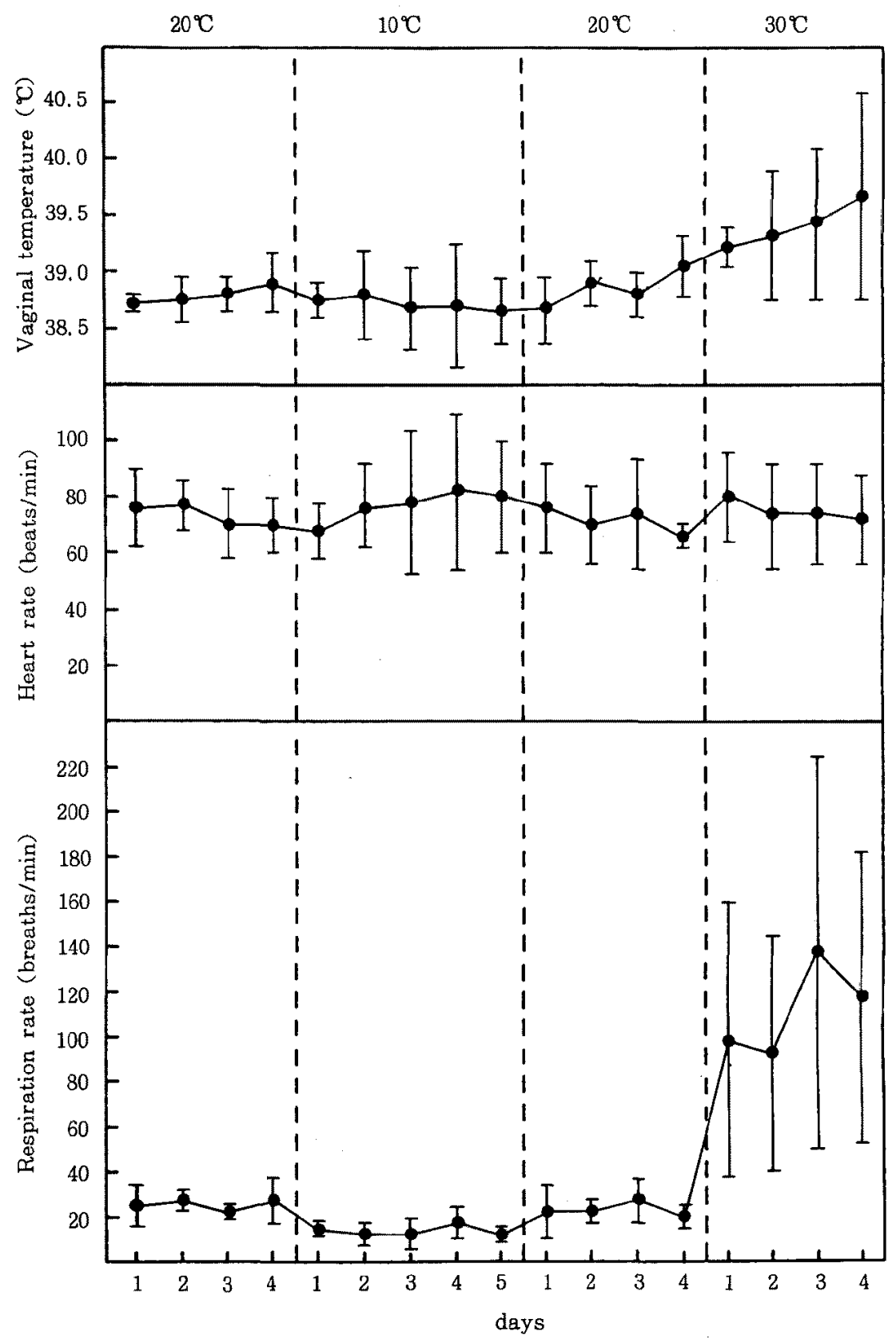

Fig. 2. Physiological responses in calves before, during cold $\left(10^{\circ} \mathrm{C}\right)$ and heat exposure $\left(30^{\circ} \mathrm{C}\right)$. Each point represents the average value of four Holstein calves. Vertical bars, S.D. of each average value. 


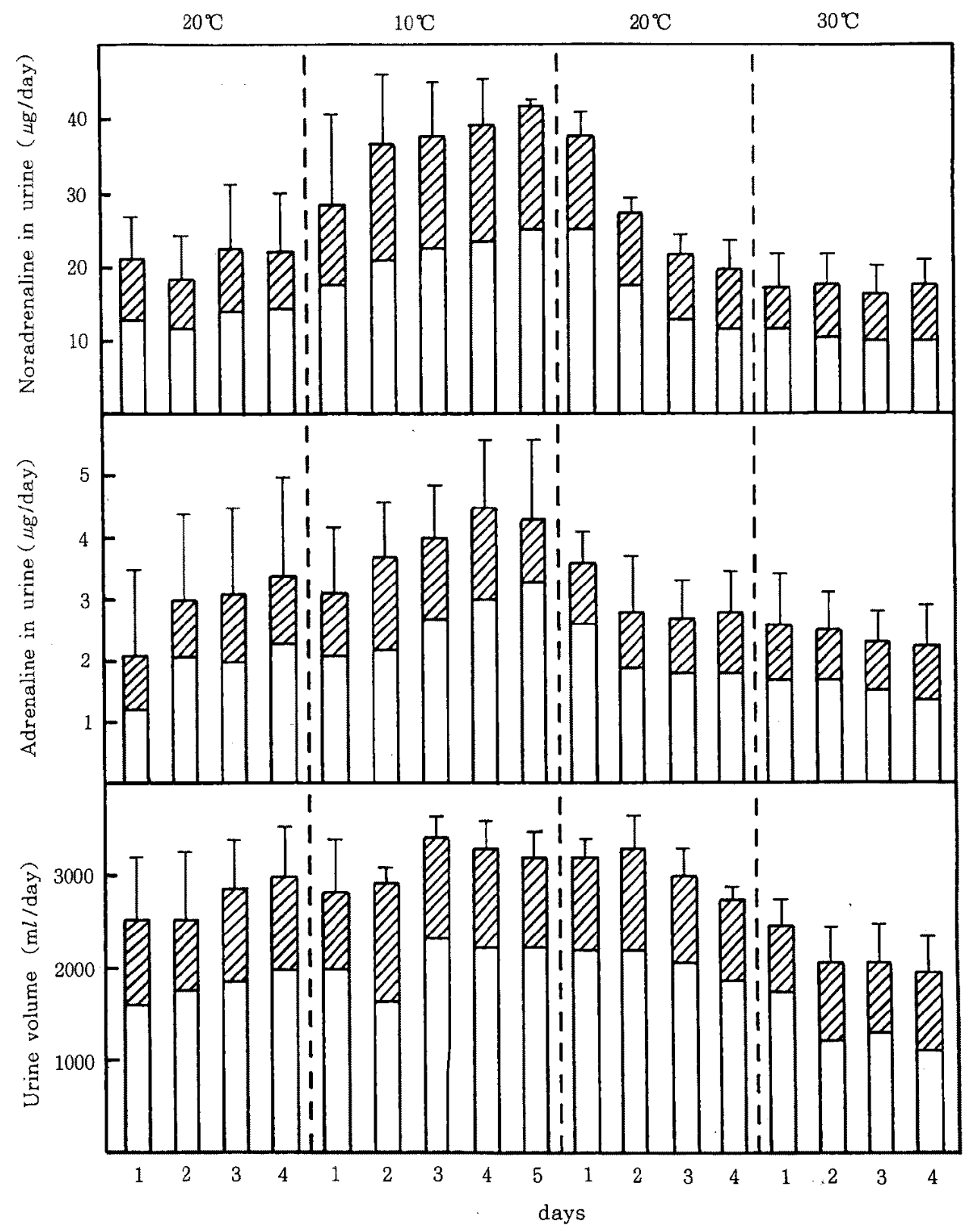

Fig. 3. Excretion of noradrenaline, adrenaline and urine volume in calves before, during cold $\left(10^{\circ} \mathrm{C}\right)$ and heat exposure $\left(30^{\circ} \mathrm{C}\right)$. Each column represents the average value of four Holstein calves ( $\square$; daytime, $\square T Z$; nighttime). Vertical bars, S.D. of each a verage value.

$(\mathrm{P}<0.05)$ and reached $41.7 \mu \mathrm{g} /$ day after four days. When the environmental temperature was returned to $20^{\circ} \mathrm{C}$, NA excretion in the first day was about equal to the end of $10^{\circ} \mathrm{C}$, but then decreased markedly after two days, reaching $19.6 \mu \mathrm{g} /$ day after three days. When the 
Table 1. Mean values with standard deviations for urine volume, urinary excretion of catecholamines and physiological responses in Holstein calves at different environmental temperatures

\begin{tabular}{lcccc}
\hline \hline & \multicolumn{4}{c}{ Fnvironmental temperature $\left(^{\circ} \mathrm{C}\right)$} \\
\cline { 2 - 5 } \multicolumn{1}{c}{ Parameter } & 20 & 10 & 20 & 30 \\
\hline Urine volume $(\mathrm{m} / /$ day $)$ & $2829 \pm 444^{\mathrm{a}}$ & $3148 \pm 193^{\mathrm{a}}$ & $3050 \pm 193^{\mathrm{a}}$ & $2123 \pm 274^{\mathrm{b}}$ \\
Noradrenaline $(\mu \mathrm{g} /$ day) & $20.9 \pm 7.3^{\mathrm{a}}$ & $38.1 \pm 7.2^{\mathrm{b}}$ & $25.1 \pm 3.2^{\mathrm{a}}$ & $16.9 \pm 3.2^{\mathrm{a}}$ \\
Adrenaline $(\mu \mathrm{g} /$ day) & $3.2 \pm 1.4^{\mathrm{a}}$ & $4.1 \pm 1.2^{\mathrm{a}}$ & $2.9 \pm 0.5^{\mathrm{a}}$ & $2.4 \pm 0.5^{\mathrm{a}}$ \\
Vaginal temperature $\left({ }^{\circ} \mathrm{C}\right)$ & $38.8 \pm 0.0^{\mathrm{ab}}$ & $38.7 \pm 0.3^{\mathrm{a}}$ & $38.9 \pm 0.1^{\mathrm{ab}}$ & $39.4 \pm 0.6^{\mathrm{b}}$ \\
Heart rate (beats/min) & $74 \pm 11^{\mathrm{a}}$ & $77 \pm 19^{\mathrm{a}}$ & $73 \pm 15^{\mathrm{a}}$ & $75 \pm 17^{\mathrm{a}}$ \\
Respiration rate & $26 \pm 5^{\mathrm{a}}$ & $14 \pm 3^{\mathrm{a}}$ & $24 \pm 10^{\mathrm{a}}$ & $111 \pm 62^{\mathrm{b}}$ \\
$\quad($ breaths/min) & & & & \\
\hline
\end{tabular}

$a, b$ : Values having same letters in the same row are not significantly different $(P<0.05)$.

environmental temperature was increased to $30^{\circ} \mathrm{C}$, NA excretion was about equal to the end of the previous period.

Changes in the daily excretion of urinary $A$ are shown in Fig. 3. Mean value of A excretion was $3.2 \mu \mathrm{g} /$ day at $20^{\circ} \mathrm{C}$. When the environmental temperature was decreased to $10^{\circ} \mathrm{C}, \mathrm{A}$ excretion increased after two days, and reached $4.3 \mu \mathrm{g} /$ day after four days. The increase in $A$ excretion, however, was not statistically significant (Table 1). When the environmental temperature was returned to $20^{\circ} \mathrm{C}$, A excretion decreased to $2.7 \mu \mathrm{g} /$ day after two days. When the environmental temperature was increased to $30^{\circ} \mathrm{C}$, A excretion was about equal to the end of the previous period.

\section{Discussion}

The finding that daily urine volume decreased with increasing environmental temperature suggests a high output of water vapor through the respiratory organs due to an increase in respiration rate (Table 1). According to AXELROD and REISINE ${ }^{3)}$, urinary excretion of NA and $A$ reflects sympathetic nervous system and adrenal medullary activity, respectively. In the calf, the adrenal medulla secrets both $\mathrm{A}$ and $\mathrm{NA}^{5,14}$. Thus, urinary output of these catecholamines in calves is correlated to both sympathetic and adrenal medullary activity.

In the present study, urinary NA excretion in calves increased by 180 percent from a ther- moneutral $\left(20^{\circ} \mathrm{C}\right)$ to a cold environment $\left(10^{\circ} \mathrm{C}\right)$, suggesting a high output of NA in cold environment, and providing indirect evidence of higher sympathetic activity during this exposure. The sympathetic response to cold in the calves observed in this study appears to be similar to the findings for NA reported ANDERSSON et $a l .{ }^{2}{ }^{2}$ for the goat and SASAKI et $a l_{.}{ }^{12)}$ for the sheep. ANDERsson et $a l .{ }^{23}$ reported that cold exposure at $-3^{\circ} \mathrm{C}$ gradually caused a 300 percent increase in NA excretion, whereas A excretion was only slightly elevated. SASAKI $e t a l .{ }^{12)}$ found that percentage increases from thermoneutral to cold exposure at $0^{\circ} \mathrm{C}$ of $\mathrm{NA}$ and $\mathrm{A}$ excretion into sheep urine was 270 and 390 , respectively. The percentage increase of A excretion from thermoneutral to cold in our study was 130 , which was considerably lower than the results of SASAKt et al. ${ }^{12)}$. They also reported the increase in heart rate during cold exposure at $0^{\circ} \mathrm{C}$. However, no significant increases in heart rate were found in this study. Lower critical temperature in newborn calves was estimated nearly $10^{\circ} \mathrm{C}^{11)}$. It appears that cold exposure at $10^{\circ} \mathrm{C}$ in this study was not sufficiently low temperature to activate thoroughly adrenal medulla in young (1-2 weeks old) Holstein calf. A slight but significant increase $(21 \%)$ in $\mathrm{NA}$ excretion at $2^{\circ} \mathrm{C}$ was reported in the $\operatorname{cow}^{1}$. The relatively small increase in catecholamine excretion in the cow exposed to cold could be explained by the fact 


\section{NAKAMURA and NEMOTO}

that the duration of exposure to the cow was not sufficiently long. As demonstrated in the present study, catecholamine excretion did not increase to maximum within one or two days after cold exposure. Our results agree with those reported by Young and LANDSBERG ${ }^{15)}$ for the rat. They found NA excretion reached a maximum several days after cold exposure.

NA and A excretion maintained relatively high levels within 24 hours after re-exposure to $20^{\circ} \mathrm{C}$, which indicates that the augmented sympathetic nervous system and adrenal medulla activity remained at high levels within 24 hours after cessatiom of cold exposure. It is suggested that acclimation of the adrenergic nervous system and adrenal medulla of the calves was achieved, at least partially, by five days exposure to $10^{\circ} \mathrm{C}$, and that the enhanced nervous system and adrenal medulla activity deacclimated after more than two days exposure to $20^{\circ} \mathrm{C}$. The rate of cold deacclimation of sympathetic nervous system in the calves found here differs from that observed in the sheep $^{12)}$. SASAKI et al. reported that the augmented adrenergic nervous system of the sheep did not deacclimate within one week of exposure to $20^{\circ} \mathrm{C}$. Our results agree with that reported by LEDUC ${ }^{9)}$ for the rat. He reported that rats housed in a cold room for one week, one month or two months recovered normal NA excretion values within two days at room temperature.

In regard to catecholamine excretion during heat exposure, no significant increases in NA nor A were found in this study. SHum et al. ${ }^{13)}$ reported an increase of $210 \%$ in the urinary excretion of $\mathrm{NA}$ in the rat during heat exposure at $36^{\circ} \mathrm{C}$. Alvarez and JoHNSON ${ }^{1)}$ reported an increase of $21 \%$ in the urinary excretion of $\mathrm{NA}$ in the cow during heat exposure at $37^{\circ} \mathrm{C}$. It should be noted, however, that the environmental temperatures used by these investigators during heat exposure differed from that employed here in calves. The data presented are indicative that urinary excretion of NA and
$\mathrm{A}$ in calves were not affected during heat exposure at $30^{\circ} \mathrm{C}$. In this study, catecholamine excretion during heat exposure was not significantly affected. However, exposure to more severe heat condition may influence catecholamine excretion.

In summary, the percentage increases in urinary $\mathrm{NA}$ and $\mathrm{A}$ excretion in Holstein calves from thermoneutral $\left(20^{\circ} \mathrm{C}\right)$ to cold exposure $\left(10^{\circ} \mathrm{C}\right)$ were 180 and 130 , respectively. Heat exposure at $30^{\circ} \mathrm{C}$, however did not significantly affect NA nor A excretion.

\section{References}

1) Alvarez, M.B. and H.D. Johnson, Urinary excretion of adrenaline and noradrenaline in cattle during heat and cold exposure. J. Dairy Sci., 53 : 928-930. 1970.

2) Andersson, B., L. Ekman, B. Hokfelt, M. Jobin, K. OLSSON and D. RoBertshaw, Studies of the importance of the thyroid and the sympathetic system in the defense to cold of the goat. Acta Physiol. Scand., 69 : 111-118. 1967.

3) Axelrod, J. and T.D. Reisine, Stress hormones: their interaction and regulation. Science, 224 : 452-459. 1984.

4) Budd, G.M. and N. WArhafT, Urinary excretion of adrenal steroids, catecholamines and electrolytes in man, before and after acclimatization to cold in antarctica. J. Physiol., 210 : 799-806. 1970.

5) Edwards, A.V., P.N. Furness and K.B. HeLle, Adrenal medullary responses to stimulation of the splanchnic nerve in the conscious calf. J. Physiol., 308: 15-27. 1980.

6) Eriksson, B.M. and B.A. Persson, Determination of catecholamines in rat heart tissue and plasma samples by liquid chromatography with electrochemical detection. J. Chromatogr., 228 : 143-154. 1982.

7) Feller, R.P. and H.B. Hale, Human urinary catecholamines in relation to climate. J. Appl. Physiol., 19 : 37-39. 1964.

8) Hale, H.B., E.W. Williams and J.P. Ellis, $\mathrm{J}_{\mathrm{R}}$, Catecholamine excretion during heat deacclimatization. J. Appl. Physiol., 18: 1206-1208. 1963.

9) Leduc, J., Catecholamine production and 
release in exposure and acclimation to cold. Acta Physiol. Scand., 53, Suppl., 183 : 1-101. 1961.

10) MORI, K., Automated measurement of catecholamines in urine, plasma and tissue homogenates by high-performance liquid chromatography with fluorometric detection. J. Chromatogr., 218: 631-637. 1981.

11) NRC, Effect of Environment on Nutrient Requirements of Domestic Animals. 10-11. National Academy Press. Washington, D.C. 1981.

12) Sasaki, Y., S. Oshiro, M. MiUra and T. TSUDA, Urinary excretion of noradrenaline and adrenaline in sheep before, during and after cold exposure. Jpn. J. Zootech. Sci., $44: 222-231.1973$.

13) Shum, A., G.E. Johnson and K.V.
FlatTERY, Influence of ambient temperature on excretion of catecholamines and metabolites. Am. J. Physiol., 216: 1164 1169. 1969.

14) Silver, M., The output of adrenaline and noradrenaline from the adrenal medulla of the calf. J. Physiol., 152: 14-29. 1960.

15) Young, J.B. and L. LANDSBERG, Effect of concomitant fasting and cold exposure on sympathoadrenal activity in rats. Am. J. Physiol., 240 : E314-E319. 1981.

16) Yul, Y., M. KimurA, $Y$. ITOKAWA and C. KaWAI, Ultramicro method for the determination of picogram amounts of norepinephrine and epinephrine by highperformance liquid chromatography. J. Chromatogr., 177 : 376-379. 1979.

\title{
暑熱抢よび寒冷時におけるホルスタイン子牛の尿中 アドレナリンおよびノルアドレナリン排泄量
}

\author{
中村正斗・根本 鉄 \\ 農林水産省畜産試験場，茨城紧筑波農林研究団地 305
}

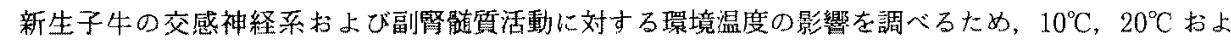
び $30^{\circ} \mathrm{C}$ に制御された環境調節室内におけるホルスタイン子牛の尿中アドレナリンおよびノルアドレナ リン排泄量を，高速液体クロマトグラフィートリ八イドロキシインドール法により営光定量した。生捘 1 2 週踰のホルスタイン继隹子牛 4 頭を供試し，尿道カテーテルを膀胱に留置して全尿採取した，子牛 は $20^{\circ} \mathrm{C}$ で 5 日間飼育後， $10^{\circ} \mathrm{C}, 20^{\circ} \mathrm{C}$ 扰よび $30^{\circ} \mathrm{C}$ にそれぞれ 4 ないし 5 日間感作した。 子牛には 1 日

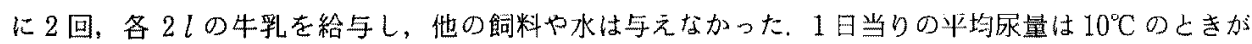
最大で，環境温度が上昇するに従って隇少した， $30^{\circ} \mathrm{C}$ のきの 1 日当りの平均尿量は，他の環境温度 に比べて有意 $(\mathrm{P}<0.05)$ に少なかった，子牛を $10^{\circ} \mathrm{C}$ に感作する之，1 日当りの平均/ルアドレナリン

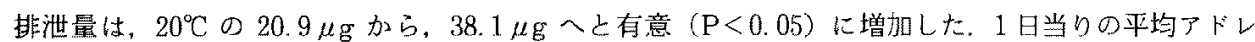
ナリン排泄量は, $20^{\circ} \mathrm{C} の 3.2 \mu \mathrm{g}$ 加ら, $10^{\circ} \mathrm{C}$ の $4.1 \mu \mathrm{g}$ へと増加した. $30^{\circ} \mathrm{C}$ の感作では, 录中アドレ ナリンおよびノルアドレナリン排泄量は $20^{\circ} \mathrm{C}$ に比べて有意な影響は認められなかった。

日畜会報，63(11)：1134-1141，1992 